\title{
EFEK PEMBERIAN ANABOLIK ANDROGENIK STEROID INJEKSI DOSIS RENDAH DAN TINGGI TERHADAP GAMBARAN MORFOLOGI TESTIS WISTAR (Rattus novergicus)
}

\author{
${ }^{1}$ Jimmy Wongkar \\ ${ }^{2}$ Meilany F. Durry \\ ${ }^{2}$ Carla F. Kairupan \\ ${ }^{1}$ Kandidat Skripsi Fakultas Kedokteran Universitas Sam Ratulangi Manado \\ ${ }^{2}$ Bagian Patologi Anatomi Fakultas Kedokteran Universitas Sam Ratulangi \\ Manado \\ Email: Jimmy.wongkar@yahoo.co.id
}

\begin{abstract}
Background: Anabolic androgenic steroids (AAS) are synthetic derivatives of endogenous male sex hormone testosterone, which stimulate protein synthesis and masculinization process. The use of AAS without indication can cause negative side effects on the reproductive system, especially in men. Androgenic anabolic steroids may interfere with the regulation of testosterone and gonadotropin hormone that may lead to sexual dysfunction, infertility (disruption of spermatogenesis) and testicular atrophy.

Objective: To determine the morphology of wistar testes, treated with anabolic androgenic steroids injection at a low and high doses.

Methods: Research subjects were 21 wistar rats divided into 7 groups. Group A were treated with standard pellets for 56 days (negative control), termination on day 29, 43, 57. Group B treated with low dose of AAS anabolic treatment and standard pellets for 28 days, termination on the $29^{\text {th }}$ day. Group C treated with low dose of AAS anabolic treatment and standard pellets for 42 days, termination on the $43^{\text {rd }}$ day . Group D treated with AAS injection on low dose and standard pellets for 56 days, termination on the $57^{\text {th }}$ day. Group E treated with AAS injection on a high dose and standard pellets for 28 days, termination on the $29^{\text {th }}$ day. Group F treated with AAS injection on a high dose and standard pellets for 42 days, termination on the $43^{\text {rd }}$ day. Group $G$ was given high-dose injection AAS treatment and standard pellets for 56 days, termination on the $57^{\text {th }}$ day.

Results: Group A showed normal testicular morphology and spermatogenesis. Group B showed disruption of spermatogenesis but testicular atrophy did not occur. Groups C and D showed disruption of spermatogenesis and testicular atrophy. Group E showed disruption of spermatogenesis but testicular atrophy did not occur. Group $\mathrm{F}$ and $\mathrm{G}$ showed an improvement on spermatogenesis and testicular atrophy did not occur.

Conclusions: Administration of low doses of anabolic androgenic steroids injection caused morphological change in rat's testes manifested as atrophy in 4 weeks, while after administration of high doses anabolic androgenic steroids injection also caused morphological change in rat's testesin the form of fewer interstitial cell compared to negative control. However administration for longer
\end{abstract}


than 6 weeks does not cause athropy. The effects of AAS on various other organs were not tested in this study.

Keywords: Anabolic androgenic steroids, atrophy, testicular.

\begin{abstract}
Abstrak:
Latar Belakang: Anabolik androgenik steroid (AAS) adalah derivat sintesis dari hormon sex testosteron endogen pria yang merangsang proses sintesis protein dan maskulinisasi. Penggunaan AAS tanpa indikasi memberikan efek samping yang buruk pada sistem reproduksi terutama pada pria. Anabolik androgenik steroid dapat mengganggu regulasi hormon testosteron dan gonadotropin sehingga dapat menyebabkan terjadinya disfungsi seksual, infertilitas (terganggunya spermatogenesis) dan atrofi testis.
\end{abstract}

Tujuan: Untuk mengetahui gambaran morfologi testis wistar yang diberikan anabolik androgenik steroid (AAS) injeksi dosis rendah dan dosis tinggi.

Metode: Subjek penelitian berupa 21 ekor wistar yang dibagi menjadi 7 kelompok. Kelompok A diberi pelet standar selama 56 hari (kontrol negatif), terminasi pada hari ke-29, 43, 57. Kelompok B diberi perlakuan AAS injeksi dosis rendah dan pelet standar selama 28 hari, terminasi hari ke-29. Kelompok C diberi perlakuan AAS injeksi dosis rendah dan pelet standar selama 42 hari, terminasi hari ke-43. Kelompok D diberi perlakuan AAS injeksi dosis rendah dan pelet standar selama 56 hari, terminasi hari ke-57. Kelompok E diberi perlakuan AAS injeksi dosis tinggi dan pelet standar selama 28 hari, terminasi hari ke 29. Kelompok F diberi perlakuan AAS injeksi dosis tinggi dan pelet standar selama 42 hari, terminasi hari ke-43. Kelompok G diberi perlakuan AAS injeksi dosis tinggi dan pelet standar selama 56 hari, terminasi hari ke-57.

Hasil: Pada kelompok A didapatkan gambaran morfologi testis dan proses spermatogenesis yang normal. Pada kelompok B didapatkan gambaran proses spermatogenesis yang terganggu namun belum terjadi atrofi testis. Pada kelompok $\mathrm{C}$ dan $\mathrm{D}$ didapatkan gambaran proses spermatogenesis yang terganggu dan testis yang mengalami atrofi. Pada kelompok E didapatkan gangguan proses spermatogenesis namun tidak terjadi atrofi testis. Pada kelompok F dan G didapatkan gambaran perbaikan proses spermatogenesis dan tidak terjadi atrofi testis.

Kesimpulan: pemberian anabolik androgenik steroid injeksi dosis rendah pada wistar menyebabkan perubahan gambaran morfologi testis berupa atrofi bila diberikan lebih dari 4 minggu, sedangkan pemberian anabolik androgenik steroid injeksi dosis tinggi menyebabkan penurunan kepadatan sel intertisial tetapi tidak menyebabkan atrofi pada testis bila diberikan lebih dari 6 minggu. Efek AAS terhadap berbagai organ lain tidak diteliti dalam penelitian ini.

Kata Kunci: Anabolik androgenik steroid, atrofi , testis. 
Anabolik androgenik steroid (AAS) adalah derivat sintetis dari hormon sex testosteron endogen pria yang merangsang efek anabolik (sintesis protein) dan androgenik (maskulinisasi). ${ }^{1}$ Secara fisiologis, elevasi konsentrasi testosteron dapat menstimulasi sintesis protein sehingga berdampak pada peningkatan ukuran otot, kekuatan otot dan massa tubuh. Testosteron juga bertanggung jawab atas perkembangan dan pematangan ciri seks sekunder pria seperti pertumbuhan rambut badan, suara yang maskulin, libido, sifat agresif dan produksi sperma. ${ }^{2}$

Anabolik androgenik steroid injeksi gabungan dari beberapa jenis testosteron yang berbeda sering digunakan secara illegal oleh para atlet. Gabungan beberapa macam testosteron yang berbeda (testosteron propionat, testosteron isokaproat, testosteron phenilpropionat dan testosteron dekanoat) dan masa kerja yang berbeda pula membuat anabolik androgenik steroid injeksi gabungan memiliki masa kerja yang lebih panjang dibandingkan pemberian tunggal dari empat testosteron tersebut. $^{3}$

Penggunaan AAS tanpa indikasi yang jelas dapat memberikan efek samping yang buruk pada sistem reproduksi dan endokrin (hormonal) pria. Penggunaan AAS dapat menekan sekresi hormon testosteron endogen melalui mekanisme umpan balik negatif (negative feedback mechanism) di aksis hipotalamus hipofisis testiskular, luteinizing hormone (LH) dan follicle stimulating hormone (FSH). Gangguan pada sekresi hormon testosteron endogen, LH dan FSH dapat menyebabkan terjadinya disfungsi seksual, dan infertilitas (azoospermia dan oligozoospermia) dan penurunan ukuran testis atau atrofi testis. ${ }^{4}$ Atrofi testis merupakan perubahan regresif yang terjadi pada testis. Morfologi testis yang mengalami atrofi menunjukkan tidak adanya perkembangan sel spermatogenik, atrofi tubulus, penepisan lapisan epitel membran tubulus seminiferus serta penurunan jumlah sel interstisial. ${ }^{5}$

Efek samping yang terjadi di atas tergantung pada dosis pemakaian. Penggunaan dosis rendah dapat mengakibatkan atrofi testis dan penurunan fungsi testis (spermatogenesis) karena hambatan terhadap sekresi gonadotropin (negative feedback mechanism). Tidak diproduksi testosteron endogen menyebabkan kadar testosteron dalam testis tidak cukup untuk mempertahankan fungsi testis.

Pada penggunaan AAS dosis tinggi tidak menyebabkan atrofi serta penurunan fungsi testis karena kadar testosteron eksogen dari obat AAS cukup besar menunjang kebutuhan testis meskipun gonadotropin dan testosteron endogen dihambat. ${ }^{6}$

Hal inilah yang mendorong peneliti untuk meneliti efek pemberian AAS injeksi dosis rendah dan tinggi terhadap perubahan gambaran morfologi testis wistar (Rattus novergicus).

\section{METODE PENELITIAN}

Penelitian ini merupakan penelitian eksperimental laboratorik yang dilakukan pada periode September 2013 hingga Januari 2014 di laboratorium Patologi Anatomi Fakultas Kedokteran Universitas Sam Ratulangi, Manado. Subjek penelitian adalah 21 ekor wistar spesies Rattus novergicus jantan dan 
berumur 2-3 bulan dengan berat ratarata 200-250 gram; dibagi menjadi 7 kelompok. Kelompok A diberi pelet standar selama 56 hari (kontrol negatif),terminasi per ekor pada hari ke-29, 43, dan 57. Kelompok B diberi perlakuan AAS dosis rendah dan pelet standar selama 28 hari, terminasi hari ke-29. Kelompok C diberi perlakuan AAS injeksi dosis rendah dan pelet standar selama 42 hari, terminasi hari ke-43. Kelompok D diberi perlakuan AAS injeksi dosis rendah dan pelet standar selama 56 hari, terminasi hari ke-57. Kelompok E diberi perlakuan AAS injeksi dosis tinggi dan pelet standar selama 28 hari, terminasi hari ke 29. Kelompok F diberi perlakuan AAS injeksi dosis tinggi dan pelet standar selama 42 hari, terminasi hari ke-43. Kelompok $\mathrm{G}$ diberi perlakuan AAS injeksi dosis tinggi dan pelet standar selama 56 hari, terminasi hari ke-57.

Obat injeksi anabolik androgenik steroid yang digunakan dalam penelitian ini adalah AAS nama dagang SUSTANON 250® yang diperoleh dari salah satu apotek di kota Manado. SUSTANON 250® mengandung testosteron propionate $30 \mathrm{mg}$, testosteron phenilpropionat 60 $\mathrm{mg}$, testosteron isocaproat $60 \mathrm{mg}$ dan testosteron decanoat $100 \mathrm{mg}$; total jumlah testosteron aktif $176 \mathrm{mg} /$ 1ml. Dosis rendah dan tinggi SUSTANON 250® orang dewasa adalah 3mg/kgbb dan 10mg/kgbb setiap 2 minggu sekali. Dosis orang dewasa kemudian dikonversikan sesuai berat badan rata-rata tikus yakni 250 gram untuk 10 ekor tikus, sehingga diperoleh dosis rendah $7,5 \mathrm{mg}(0,05 \mathrm{ml})$ dan dosis tinggi 25 mg $(0,15 \mathrm{ml})$. Dosis yang telah ditetapkan dilarutkan dengan pelarut minyak jagung hingga jumlah volume masing-masing sediaan mencapai 1,25 ml kemudian diinjeksikan pada masing-masing tikus $0,1 \mathrm{ml}$ secara intramuscular (IM) tegak lurus $90^{\circ}$ perlahan-lahan pada jaringan otot musculus antero lateral. Pengulangan pemberian dosis dilakukan setiap 2 minggu sekali.

Pemberian AAS injeksi dosis rendah dan tinggi diharapkan dapat memberikan efek berupa perubahan gambaran morfologi testis wistar.

Gambaran morfologi testis yang dinilai dan diamati adalah gambaran makroskopik dan mikroskopik testis. Gambaran makroskopik testis meliputi warna, konsistensi, berat dan ukuran. Berat testis diperoleh menggunakan timbangan analitik dengan ketelitian 0,1 (tabel 1). Gambaran mikroskopik testis berupa penilaian terhadap diameter tubulus seminiferus, jumlah lapisan sel spermatogenik dan kepadatan sel interstisial.

\section{HASIL PENELITIAN}

\section{Gambaran Makroskopik}

Wistar kelompok kontrol negatif memiliki testis dengan berat dan ukuran yang relatif lebih besar dari kelompok perlakuan AAS dosis rendah dan tinggi dalam waktu perlakuan yang sama (tabel 1). Wistar kelompok perlakuan AAS dosis rendah 4 minggu memiliki berat dan ukuran testis yang relatif lebih besar dari kelompok perlakuan AAS dosis rendah lainnya dan semua kelompok perlakuan AAS dosis tinggi serta relatif lebih kecil dari kelompok kontrol negatif. Testis wistar kelompok perlakuan AAS dosis rendah 6 dan 8 minggu menunjukkan berat dan ukuran testis yang relatif lebih rendah 
dibandingkan dengan kelompok kontrol negatif, kelompok perlakuan AAS dosis rendah 4 minggu dan kelompok perlakuaan AAS dosis tinggi 4, 6, dan 8 minggu. Kelompok perlakuan AAS dosis tinggi 4 , 6 dan 8 minggu memiliki testis dengan berat dan ukuran yang relatif lebih kecil dibandingkan dengan kelompok kontrol negatif dan kelompok perlakuaan AAS dosis rendah 4 minggu tetapi relatif lebih besar dari kelompok perlakuan AAS dosis rendah 6 dan 8 minggu. Semua wistar pada kelompok kontrol negatif dan kelompok percobaan memiliki testis dengan konsistensi kenyal dan warna merah kecokelatan.

Tabel 1. Data pengukuran testis saat otopsi wistar kelompok kontrol (K-) dan kelompok perlakuan.

\begin{tabular}{|c|c|c|c|c|c|c|c|}
\hline Lama Perlakuan & Kelompok & Berat (gram) & Panjang $(\mathrm{cm})$ & Lebar $(\mathrm{cm})$ & Tebal $(\mathrm{cm})$ & Konsistensi & Warna \\
\hline \multirow{7}{*}{$a^{n}$} & A1 (K-) & 1,65 & 2 & 1 & 1,3 & Kenyal & Merah muda \\
\hline & B1 & 1,55 & 1,8 & 0,9 & 0,9 & Kenyal & Merah muda \\
\hline & B2 & 1,25 & 1,6 & 0,8 & 0,8 & Kenyal & Merah muda \\
\hline & B3 & 1,56 & 1,7 & 0,8 & 0,7 & Kenyal & Merah muda \\
\hline & E1 & 1,10 & 1,6 & 0,6 & 0,7 & Kenyal & Merah muda \\
\hline & E2 & 0,91 & 1,7 & 0,7 & 0,7 & Kenyal & Merah muda \\
\hline & E3 & 0,89 & 1,6 & 0,7 & 0,7 & Kenyal & Merah muda \\
\hline \multirow[t]{8}{*}{ Lama Perlakuan } & Kelompok & Berat (gram) & Panjang $(\mathrm{cm})$ & Lebar $(\mathrm{cm})$ & Tebal $(\mathrm{cm})$ & Konsistensi & Warna \\
\hline & A2 (K-) & 1,60 & 1,8 & 1,1 & 1,2 & Kenyal & Merah muda \\
\hline & $\mathrm{Cl}$ & 0,48 & 1,1 & 0,7 & 0,6 & Kenyal & Merah muda \\
\hline & $\mathrm{C} 2$ & 0,73 & 1,5 & 0,8 & 0,8 & Kenyal & Merah muda \\
\hline & $\mathrm{C3}$ & 0,65 & 1,3 & 0,6 & 0,6 & Kenyal & Merah muda \\
\hline & F1 & 0,75 & 1,4 & 0,7 & 0,6 & Kenyal & Merah muda \\
\hline & F2 & 1,10 & 1,4 & 0,8 & 0,7 & Kenyal & Merah muda \\
\hline & F3 & 0,80 & 1,5 & 0,75 & 0,7 & Kenyal & Merah muda \\
\hline \multirow[t]{8}{*}{ Lama Perlakuan } & Kelompok & Berat (gram) & Panjang $(\mathrm{cm})$ & Lebar $(\mathrm{cm})$ & Tebal $(\mathrm{cm})$ & Konsistensi & Warna \\
\hline & A3 (K-) & 1,54 & 2 & 1,2 & 1,1 & Kenyal & Merah kecokelatan \\
\hline & D1(mati hari ke-30) & 1,5 & 1,5 & 0,8 & 0,8 & Kenyal & Merah kecokelatan \\
\hline & D2 & 0,41 & 1,2 & 0,7 & 0,6 & Kenyal & Merah kecokelatan \\
\hline & D3 & 0,72 & 1,4 & 0,8 & 0,7 & Kenyal & Merah kecokelatan \\
\hline & G1 & 1,29 & 1,7 & 1 & 1 & Kenyal & Merah kecokelatan \\
\hline & G2 & 0,9 & 1,5 & 1 & 0,8 & Kenyal & Merah kecokelatan \\
\hline & G3 & 0,92 & 1,6 & 0,9 & 0,8 & Kenyal & Merah kecokelatan \\
\hline
\end{tabular}

\section{Gambaran Mikroskopik}

\section{Wistar kelompok A}

Pada semua sediaan testis kelompok ini tampak tubulus seminiferus dengan susunan lapisan sel spermatogenik yang normal dan sesuai dengan tingkat perkembangannya dari membran basalis ke arah lumen tubulus yakni spermatogonia, 
spermatid, hingga spermatozoon (gambar 1.a, 1.b, 1.c).

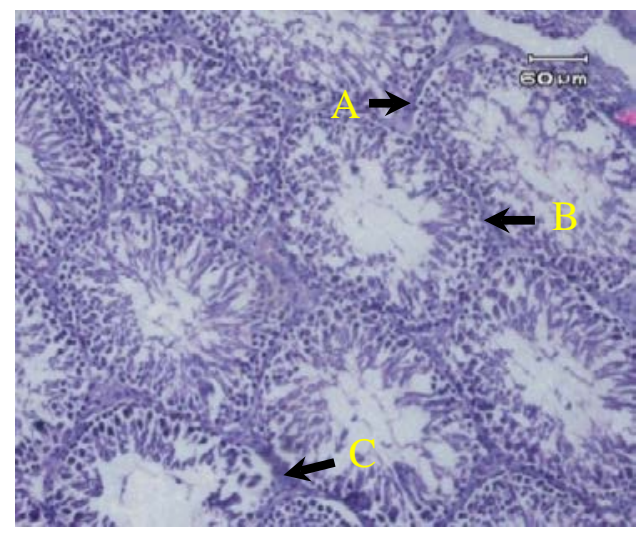

Gambar 1.a. Gambaran mikroskopik testis wistar kelompok kontrol negatif 4 minggu (A1). Tampak tubulus seminiferus (A), susunan lapisan sel spermatogenik (B) dan jaringan intestisial serta jumlah sel intertisial (C) yang normal. Pembesaran 10x10.

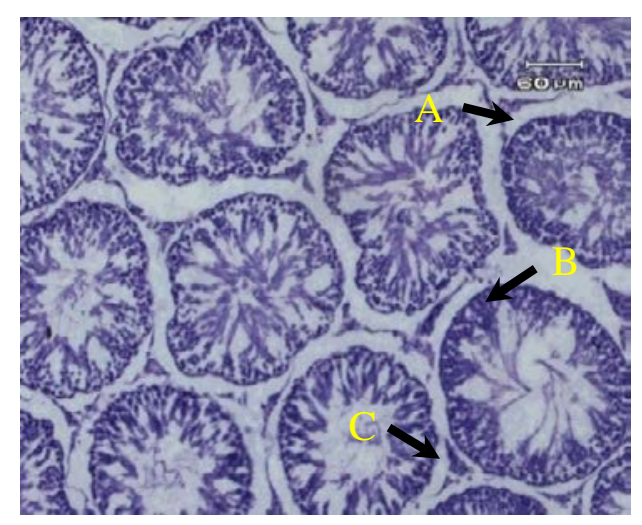

Gambar 1.b. Gambaran mikroskopik testis wistar kelompok kontrol negatif 6 minggu (A2). Tampak tubulus seminiferus (A), susunan lapisan sel spermatogenik (B) dan jaringan intestisial serta jumlah sel intertisial (C) yang normal. Pembesaran 10x10.

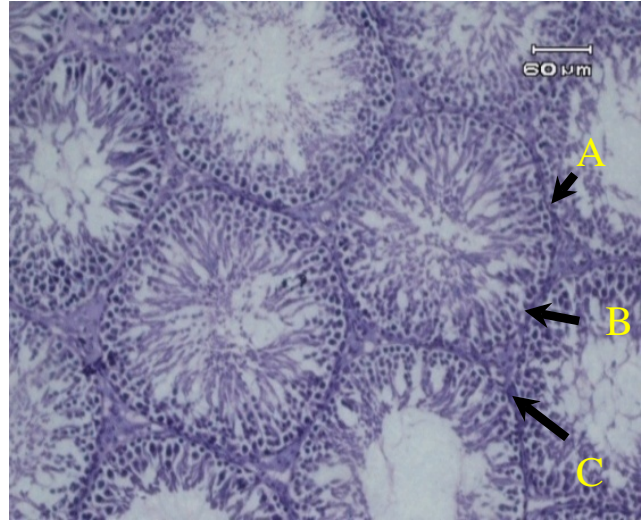

Gambar 1.c. Gambaran mikroskopik testis wistar kelompok kontrol negatif 8 minggu (A3). Tampak tubulus seminiferus yang normal (A), susunan lapisan sel spermatogenik yang normal (B) dan sel intestisial (C) yang normal. Pembesaran 10x10.

\section{Wistar kelompok B}

Pada wistar kelompok B yang diberikan AAS injeksi dosis rendah selama 4 minggu didapatkan testis yang memperlihatkan tubulus seminiferus dengan susunan lapisan sel spermatogenik yang tidak sesuai dengan perkembangannya dan jumlah sel intertisial yang lebih sedikit dibandingkan kelompok kontrol negatif. Kepadatan spermatozoa di dalam tubulus terlihat berbeda dibandingkan dengan gambaran pada kelompok kontrol yaitu pada wistar kelompok $\mathrm{B}$, daerah sekitar membran basalis tubulus sangat sedikit mengandung sel spermatogenik sehingga terlihat tubulus dengan daerah lumen yang padat namun kosong di daerah membran basalis (gambar 2). 


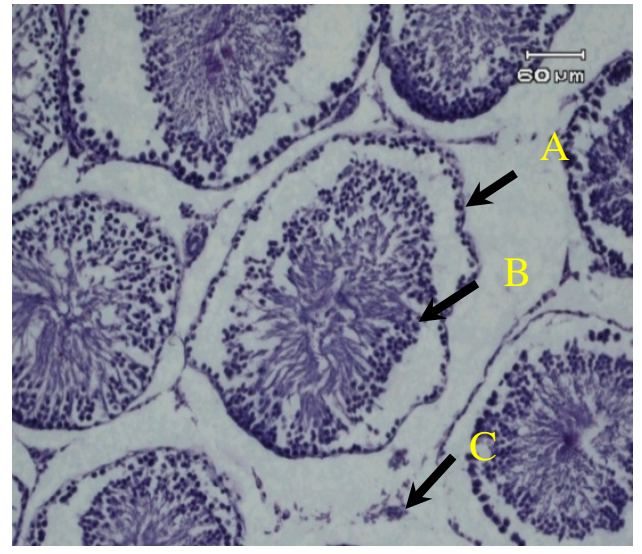

Gambar 2. Gambaran mikroskopik testis wistar kelompok B (perlakuan AAS dosis rendah selama 4 minggu). Tampak tubulus seminiferus dengan susunan sel spermatogenik yang tidak sesuai perkembangannya (A), sel spermatogenik sangat sedikit berada di daerah membran basalis dan terfokus pada daerah lumen (B) dan jumlah sel interstisial yang lebih sedikit dari jumlah sel intertisial kelompok kontrol negatif (C). Pembesaran 10x10.

\section{Wistar kelompok C}

Pada wistar kelompok C yang diberikan AAS injeksi dosis rendah selama 6 minggu didapatkan testis yang memperlihatkan jumlah sel intertisial lebih sedikit dibandingkan kelompok kontrol negatif, tubulus seminiferus tanpa perkembangan sel spermatogenik. Kepadatan spermatozoa terlihat berbeda dengan kelompok kontrol negatif dan semua kelompok perlakuan 4 minggu dan kelompok perlakuan 6 minggu dosis tinggi yaitu pada wistar kelompok D hanya terdapat spermatogonia pada membran basalis sehingga memperlihatkan ruang tubulus seminiferus yang kosong tanpa perkembangan sel-sel spermatogenik (gambar 3).

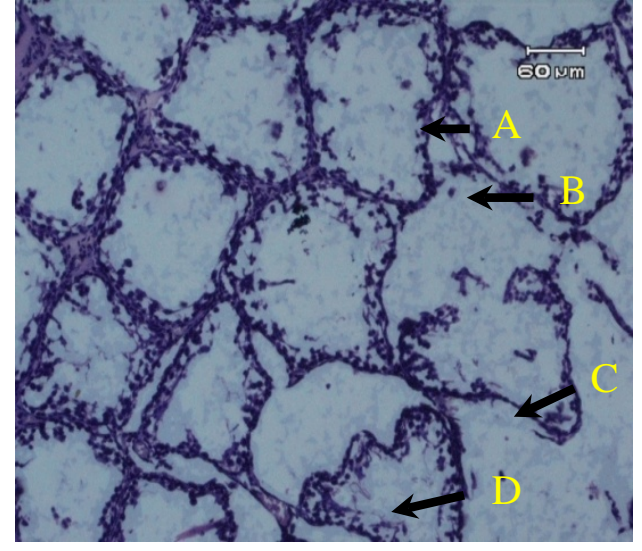

Gambar 3. Gambaran mikroskopik testis wistar kelompok C (perlakuan AAS dosis rendah selama 6 minggu). Tampak tubulus seminiferus tanpa perkembangan sel spermatogenik (A), jumlah sel interstisial lebih sedikit dari jumlah sel intertisial kelompok kontrol negatif (B), susunan lapisan sel spermatogenik hanya tersisa selapis (C) sehingga ruang tubulus tampak kosong (D). Pembesaran 10x10.

\section{Wistar kelompok D}

Pada wistar kelompok D yang diberikan AAS injeksi dosis rendah selama 8 minggu didapatkan gambaran histopatologi testis yang memperlihatkan jumlah sel intertisial yang lebih sedikit dibandingkan jumlah sel intertisial kelompok kontrol negatif dan tubulus seminiferus tanpa perkembangan sel germinal. Kepadatan spermatozoa terlihat berbeda dengan kelompok kontrol negatif, semua kelompok perlakuan 4 minggu, kelompok perlakuan 6 minggu dosis tinggi dan kelompok dosis tinggi 8 minggu tetapi memiliki kepadatan yang sama dengan kelompok perlakuan dosis rendah 6 minggu. Spermatognia hanya terdapat pada membran basalis sehingga ruang tubulus seminiferus tampak kosong (gambar 4). 


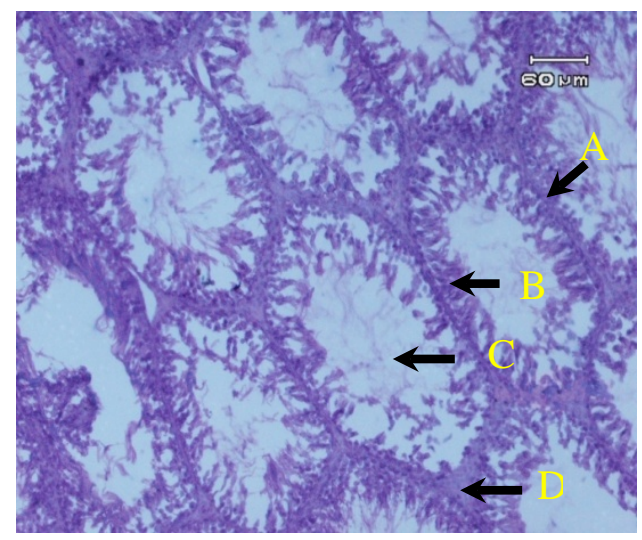

Gambar 4. Gambaran mikroskopik testis wistar kelompok D (perlakuan AAS dosis rendah selama 8 minggu). Tampak tubulus seminiferus tanpa perkembangan sel germinal (A), susunan lapisan sel spermatogenik hanya tersisa selapis (B) sehingga ruang tubulus tampak kosong (C) dan jumlah sel interstisial lebih sedikit dibandingkan jumlah sel intertisial kelompok kontrol negatif (D). Pembesaran 10x10.

\section{Wistar kelompok E}

Wistar kelompok E yang diberikan AAS injeksi dosis tinggi selama 4 minggu didapatkan gambaran histopatologi testis yang memperlihatkan tubulus seminiferus dengan susunan lapisan sel spermatogenik yang tidak sesuai dengan perkembangannya dan jumlah sel intertisial yang lebih sedikit dibandingkan jumlah sel intertisial kelompok kontrol negatif. Kepadatan spermatozoa terlihat berbeda dibandingkan dengan kelompok kontrol negatif tetapi memiliki gambaran yang identik dengan kelompok perlakuan dosis rendah 4 minggu yaitu pada wistar kelompok E, daerah sekitar membran basalis tubulus sangat sedikit mengandung sel spermatogenik sehingga terlihat tubulus dengan daerah lumen yang padat namun kosong didaerah membran basalis (gambar 5).

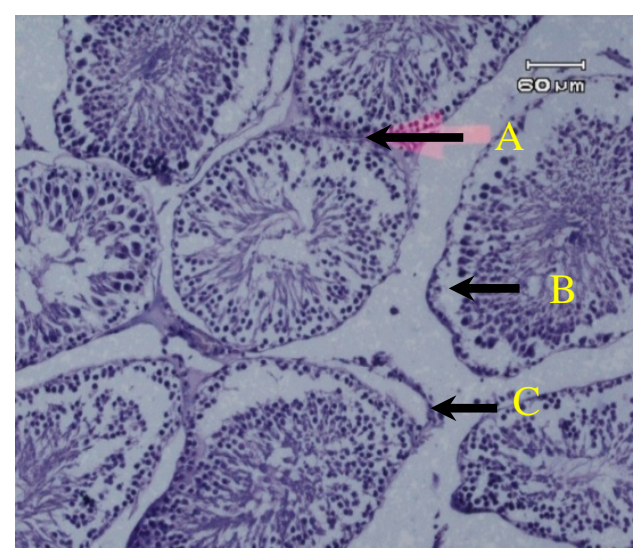

Gambar 5. Gambaran mikroskopik testis wistar kelompok E (perlakuan AAS dosis tinggi selama 4 minggu). Tampak tubulus seminiferus dengan susunan sel spermatogenik yang tidak sesuai perkembangannya (A), sel spermatogenik sangat sedikit berada di daerah membran basalis dan terfokus pada daerah lumen (B) dan jumlah sel intertisial lebih sedikit dibandingkan jumlah sel intertisial kelompok kontrol negatif (C). Pembesaran 10x10.

\section{Wistar kelompok $F$}

Pada wistar kelompok $\mathrm{F}$ yang diberikan anabolik androgenik steroid injeksi dosis tinggi selama 6 minggu didapatkan gambaran histopatologi testis yang memperlihatkan tubulus seminiferus dengan susunan lapisan sel spermatogenik yang longgar namun sesuai tingkat perkembangannya dan jumlah sel intertisial yang lebih sedikit dibandingkan kelompok kontrol negatif. Kepadatan spermatozoa terlihat berbeda dengan kelompok kontrol negatif, kelompok perlakuan dosis rendah 4 dan 6 minggu dan kelompok perlakuan dosis tinggi 6 minggu yaitu pada wistar kelompok $\mathrm{F}$ daerah sekitar membran basalis terdapat sedikit lapisan susunan sel spermatogenik yang masih dalam proses 
pembelahan sedangkan di daerah lumen sangat sedikit dan hampir tidak ada sel spermatogenik (gambar 6).

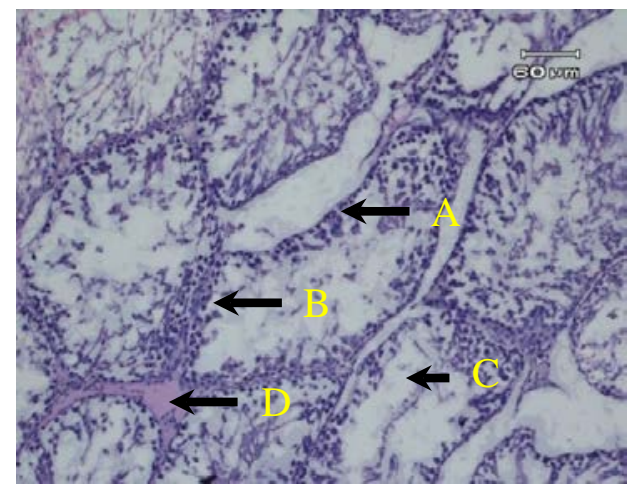

Gambar 6. Gambaran mikroskopik testis wistar kelompok $F$ (perlakuan AAS dosis tinggi selama 6 minggu). Tampak tubulus seminiferus dengan susunan lapisan sel spermatogenik yang longgar dan sesuai tingkat perkembangannya (A), susunan beberapa lapisan sel spermatogenik (B), sangat sedikit sel spermatogenik di daerah lumen tubulus (C) dan jumlah sel intertisial lebih sedikit dibandingkan jumlah sel intertisial kelompok kontrol negatif (D). Pembesaran 10x10.

\section{Wistar kelompok G}

Pada wistar kelompok $G$ yang diberikan AAS injeksi dosis tinggi selama 8 minggu didapatkan gambaran histopatologi testis yang memperlihatkan tubulus seminiferus dengan susunan lapisan sel spermatogenik yang sesuai tingkat perkembangannya dan jumlah sel intertisial lebih sedikit dibandingkan kelompok kontrol negatif. Kepadatan spermatozoa terlihat hampir sama dengan kelompok kontrol negatif tetapi berbeda dengan semua kelompok perlakuan mulai dari 4, 6, hingga 8 minggu yaitu pada wistar kelompok $\mathrm{G}$ daerah sekitar membran basalis terdapat banyak lapisan sel spermatogenik yang masih dalam proses pembelahan (gambar 7).

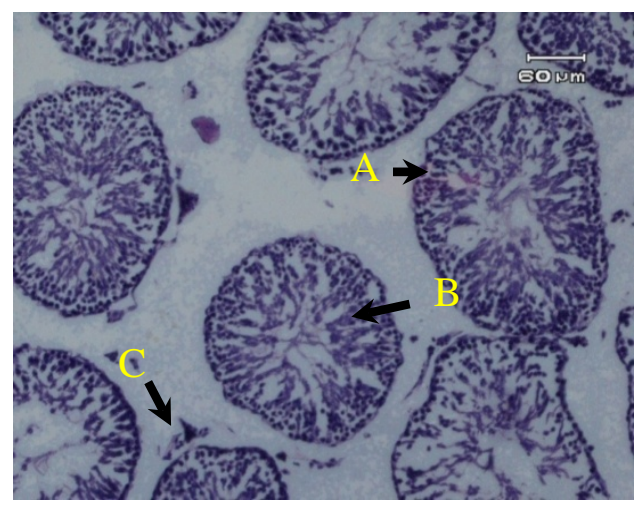

Gambar 7. Gambaran mikroskopik testis wistar kelompok G (perlakuan AAS dosis tinggi selama 8 minggu). Tampak tubulus seminiferus dengan susunan lapisan sel spermatogenik yang sesuai tingkat perkembangannya (A), terdapat banyak susunan lapisan sel spermatogenik di daerah membran basalis tubulus (B), jumlah sel intertisial lebih sedikit dibandingkan jumlah sel intertisial kelompok kontrol negatif (C). Pembesaran 10x10.

\section{Pengukuran Diameter Tubulus}

Pengukuran diameter tubulus dilakukan dengan cara mengukur jarak terpanjang dan jarak terpendek dari tubulus seminiferus yang bentuknya bulat atau dianggap bulat menggunakan mistar (mm) pada sediaan jaringan testis dengan pembesaran yang sama (10x10). Jumlah tubulus yang diukur adalah 4 tubulus dari tiap-tiap sediaan jaringan kemudian dihitung nilai rata-ratanya. Hasil pengukuran dalam skala milimeter kemudian dikonversi ke dalam skala mikrometer dengan berpatokan pada jarak kalibrasi mikroskop yakni $60 \mu \mathrm{m}$ sama dengan $70 \mathrm{~mm}$. Jadi rumus untuk mencari diameter tubulus yaitu $60 \mu \mathrm{m}$ dibagi 
$70 \mathrm{~mm}$ dikali ukuran jarak (mm) (tabel 2).

Pengamatan jumlah lapisan sel

Pengamatan jumlah lapisan sel spermatogenik pada tubulus dilakukan secara melingkar pada 4 tubulus yang berdekatan dengan menghitung jumlah lapisan sel sperma tidak terputus kemudian dihitung nilai rata-ratanya( tabel 3).
Pengamatan kepadatan sel intertisial

Pengamatan jumlah sel intertisial dilakukan secara kualitatif dengan cara melihat kumpulan sel intertisial yang berada diantara 3 sampai 4 tubulus seminiferus dalam 4 lapang pandang dengan pembesaran 10x10.

Tabel 2. Hasil pengukuran diameter tubulus $(\mu \mathrm{m})$.

\begin{tabular}{cccccccccc}
\hline \multirow{2}{*}{ kelompok } & \multicolumn{3}{c}{ Diameter terjauh $(\mu \mathrm{m})$} & \multicolumn{5}{c}{ Diameter terdekat $(\mu \mathrm{m})$} & \multirow{2}{*}{ Rata rata $(\mu \mathrm{m})$} \\
\cline { 2 - 9 } & Tubulus 1 & Tubulus 2 & Tubulus 3 & Tubulus 4 & Tubulus 1 & Tubulus 2 & Tubulus 3 & Tubulus 4 & \\
\hline A1 & 257.1 & 239.96 & 231.39 & 214.25 & 154.26 & 171.4 & 179.97 & 154.26 & 200.32375 \\
\hline A2 & 214.25 & 222.82 & 257.1 & 188.54 & 154.26 & 162.83 & 154.26 & 162.83 & 189.61125 \\
\hline A3 & 239.96 & 214.25 & 222.82 & 214.25 & 214.25 & 214.25 & 214.25 & 171.4 & 213.17875 \\
\hline & & & & & & & & & \\
\hline B & 248.53 & 188.54 & 214.25 & 257.1 & 222.82 & 188.54 & 179.97 & 188.54 & 211.03625 \\
\hline C & 145.69 & 154.26 & 154.26 & 171.4 & 128.55 & 145.69 & 145.69 & 179.97 & 153.18875 \\
\hline D & 205.68 & 197.11 & 257.1 & 222.82 & 154.26 & 119.98 & 128.55 & 128.55 & 176.75625 \\
\hline & & & & & & & & & \\
\hline E & 239.96 & 291.38 & 197.11 & 222.82 & 171.4 & 162.83 & 162.83 & 154.26 & 200.32375 \\
\hline F & 214.25 & 257.1 & 222.82 & 214.25 & 145.69 & 171.4 & 119.98 & 171.4 & 189.61125 \\
\hline G & 188.54 & 214.25 & 222.82 & 197.11 & 171.4 & 171.4 & 197.11 & 188.54 & 193.89625 \\
\hline
\end{tabular}

Tabel 3. Hasil pengamatan jumlah lapisan sel spermatogenik tubulus setiap kelompok.

\begin{tabular}{ccccccc}
\hline \multirow{2}{*}{ kelompok } & \multicolumn{5}{c}{ Jumlah lapisan } & \multirow{2}{*}{ rata rata } \\
\cline { 2 - 6 } & Tubulus 1 & Tubulus 2 & Tubulus 3 & Tubulus 4 & \\
\hline A1 & 4 & 5 & 4 & 4 & 4.25 \\
\hline A2 & 5 & 3 & 5 & 3 & 4 \\
\hline A 3 & 5 & 5 & 4 & 3 & 4.25 \\
\hline B & 3 & 3 & 5 & 3 & 3.5 \\
\hline C & 1 & 1 & 1 & 1 & 1 \\
\hline D & 1 & 1 & 1 & 1 & 1 \\
\hline E & 4 & 3 & 4 & 3 & 3.5 \\
\hline F & 2 & 2 & 2 & 1 & 1.75 \\
\hline G & 4 & 4 & 4 & 3 & 3.75 \\
\hline
\end{tabular}




\section{PEMBAHASAN}

Anabolik androgenik steroid (AAS) merupakan derivat sintetis dari hormon seks testosteron endogen pria (testosteron eksogen). Karila (2003) ${ }^{4}$ dan Ascobat (2007) ${ }^{6}$ menyatakan bahwa penggunaan AAS dapat menekan fungsi sekresi hormon testosteron endogen dan hormon gonadotropin melalui mekanisme umpan balik negatif pada aksis hipotalamus-hipofisistestikular. Penekanan kedua hormon ini dapat menyebabkan terjadinya disfungsi seksual, infertilitas (azoospermia dan oligozoospermia) dan penurunan ukuran testis atau atrofi testis.

Pada pemberian AAS dosis tinggi tidak menyebabkan atrofi dan penurunan fungsi testis karena kadar testosteron eksogen dari obat AAS cukup untuk menunjang kebutuhan testis dalam proses spermatogenesis meskipun gonadotropin dan testosteron endogen dihambat. Penelitian ini membuktikan adanya pengaruh AAS terhadap morfologi testis khususnya gambaran mikroskopik tubulus seminiferus.

Berhentinya perkembangan sel spermatogenik akibat penekanan sekresi hormon testosteron endogen dan hormon gonadotropin menyebabkan penurunan dan perubahan dari susunan lapisan sel spermatogenik seperti yang terlihat pada gambaran mikroskopik kelompok perlakuan AAS dosis rendah. Gambaran mikroskopik testis kelompok wistar yang diberi perlakuan AAS dosis rendah (kelompok B, C, dan D) memperlihatkan tubulus semeniferus dengan susunan lapisan sel spermatogenik yang tidak teratur dan tidak sesuai dengan perkembangannya (kelompok B) serta tidak terjadi perkembangan sel spermatogenik (kelompok C dan D). Hal ini disebabkan karena pemberian anabolik androgenik dosis rendah dapat menyebabkan terjadinya mekanisme umpan balik negatif sehingga proses perkembangan sel spermatogenik terhenti. Kepadatan sel spermatogenik pada kelompok B terfokus pada daerah lumen sehingga tampak seperti adanya celah atau rongga pada daerah sekitar membran basalis (gambar 2) dan pada kelompok C dan D terlihat ruang tubulus yang kosong tanpa perkembangan sel-sel spermatogenik. Diduga bahwa pada kelompok perlakuan 4 minggu (kelompok B) AAS telah menekan proses spermatogenesis tetapi menyisakan sel spermatogenik yang telah ada sebelum pemberian AAS. Pada jangka waktu yang lebih lama terhentinya perkembangan sel spermatogenik ini pada akhirnya hanya akan menyisakan ruang tubulus yang kosong karena sel spermatozoa yang telah terbentuk sebelum pemberian AAS akan bergerak ke dalam lumen seperti yang terrlihat pada kelompok $\mathrm{C}$ dan $\mathrm{D}$ (gambar 3 dan gambar 4). Temuan ini didukung oleh data pengukuran nilai rata-rata diameter tubulus (tabel 2). Berkurangnya lapisan sel spermatogenik akibat penekanan pada proses spermatogenesis menyebabkan dorongan spermatozoa dari dalam tubulus menjadi berkurang sehingga diameter dari tubulus juga berkurang. Hal ini sesuai dengan hasil penelitian Sugeng (2010) $)^{7}$ yang menyatakan bahwa gangguan perkembangan spermatozoa dapat mengakibatkan penurunan pada diameter tubulus seminiferus. 
Temuan yang menarik untuk dibahas adalah gambaran mikroskopik testis wistar kelompok perlakuan AAS dosis tinggi 4, 6, dan 8 minggu (kelompok E, F dan G). Wistar kelompok E memiliki testis dengan gambaran mikroskopik yang menyerupai testis wistar kelompok perlakuan dosis rendah ( kelompok B, C, dan D). Berbeda dengan kelompok E, gambaran mikroskopik testis wistar kelompok F dan G lebih menyerupai kelompok kontrol negatif. Meskipun testosteron endogen dihambat, pada pemberian anabolik AAS di atas 4 minggu diduga terjadi peningkatan kadar testosteron eksogen yang dapat memenuhi kebutuhan testis dalam proses spermatogenesis. Perbedaan dalam hal kepadatan sel spermatogenik menunjang dugaan tersebut. Wistar kelompok G memiliki kepadatan sel spermatogenik yang jauh lebih padat (gambar 7) dibandingkan dengan kelompok E yang kepadatannya hanya terfokus di daerah lumen (gambar 5) dan kelompok F yang kepadatannya hanya terfokus di daerah sekitar membran basalis (gambar 6). Terhentinya perkembangan sel spermatogenik pada waktu yang lama akan menyisakan ruang tubulus yang kosong. Pada saat kadar testosteron eksogen telah cukup menunjang kebutuhan testis dalam proses spermatogenesis maka akan terbentuk sel spermatogenik baru. Sebagaimana yang terlihat pada kelompok $F$ dan $G$ yaitu adanya lapisan spermatogenik yang sedang berkembang sesuai dengan perkembangannya (gambar 6 dan 7).

Hasil pengukuran diameter tubulus seminiferus wistar pada kelompok perlakuan AAS dosis tinggi menunjukkan nilai rata-rata yang relatif sedikit lebih rendah dari kelompok kontrol negatif dan relatif lebih tinggi dari kelompok perlakuan AAS dosis rendah (tabel 2). Pada kelompok perlakuan AAS dosis tinggi 4 minggu terjadi penekanan awal terhadap proses spermatogenesis sehingga diameter tubulus tidak banyak mengalami perubahan. Jika perlakuan dilanjutkan sampai 6 dan 8 minggu maka akan terjadi perbaikan spermatogenesis sehingga diameter tubulus lebih besar dibandingkan dengan diameter pada wistar kelompok perlakuan AAS dosis tinggi 4 minggu (tabel 2). Hal ini sejalan dengan penelitian Anindita $(2008)^{8}$ yang menyatakan bahwa peningkatan proses spermatogenesis dapat meningkatkan diameter tubulus seminiferus dan berat testis.

Sedikitnya jumlah dari sel intertisial pada pemberian AAS dosis rendah dan dosis tinggi diduga terjadi akibat degenerasi sel-sel intertisial oleh karena tidak adanya rangsangan hormon gonadotropin terhadap sel intertisial. Hal yang serupa dibuktikan dalam penelitian Hijazi et al (2012) ${ }^{9}$ dimana pemberian AAS menyebabkan terjadinya degenerasi sel germinal dan sel leydig melalui mekanisme apoptosis akibat kurangnya perangsangan hormon gonadotropin.

Gambaran mikroskopik testis wistar pada penelitian ini juga juga ditunjang dengan hasil penilaian gambaran makroskopiknya. Wistar kelompok perlakuan AAS dosis rendah yang mengalami hambatan dalam perkembangan sel spermatogenik dan penurunan diameter tubulus ternyata memiliki berat dan ukuran testis yang lebih rendah dibandingkan dengan wistar 
kelompok kontrol negatif dan kelompok perlakuan AAS dosis tinggi (tabel1). Hal ini sesuai dengan penelitian Anindita $(2008)^{8}$, yaitu penurunan jumlah sel spermatogenik dapat menyebabkan penurunan berat testis, begitu juga sebaliknya peningkatan jumlah sel spermatogenik dapat menyebabkan peningkatan berat testis.

\section{SIMPULAN}

\begin{abstract}
Berdasarkan hasil penelitian ini dapat disimpulkan bahwa pemberian anabolik androgenik steroid injeksi dosis rendah pada wistar menyebabkan perubahan gambaran morfologi testis berupa atrofi bila diberikan lebih dari 4 minggu, sedangkan pemberian anabolik androgenik steroid injeksi dosis tinggi menyebabkan penurunan kepadatan sel intertisial tetapi tidak menyebabkan atrofi pada testis bila diberikan lebih dari 6 minggu.
\end{abstract}

\section{SARAN}

Keterbatasan pada penelitian ini antara lain; jumlah hewan coba yang digunakan masih terlalu sedikit, diperlukan pemeriksaan kadar testosteron untuk menyingkirkan kondisi hipogonadisme yang dapat mengganggu hasil penelitian, dibutuhkan waktu penelitian yang lebih lama untuk melihat lebih jauh efek pemberian anabolik androgenik steroid dalam tingkatan dosis yang berbeda terhadap gambaran morfologi testis, diperlukan penelitian lebih lanjut mengenai efek pemberian anabolik androgenik steroid injeksi dosis rendah dan tinggi terhadap gambaran morfologi berbagai organ lain untuk menilai tingkat keamanan penggunaan obat tersebut dan diperlukan pemeriksaan penunjang jumlah sel intertisial secara kuantitatif.

\section{UCAPAN TERIMA KASIH}

Ucapan terima kasih kepada Dr. dr. Lidya Tendean, M.Repro, Sp.And dan dr. Poppy M. Lintong, Sp.PA $(\mathrm{K})$, serta semua pihak yang secara langsung maupun tidak langsung yang telah memberi ide maupun gagasan kepada penulis sehingga penulis dapat menyelesaikan artikel ini.

\section{DAFTAR PUSTAKA}

1. Skarberg K, Nyberg F, Engstrom I. The development of multiple drug use among anabolic-androgenic steroid users: six subjective case report. BioMed Central. 2008;3.

2. Bhasin S, Woodhouse L, Storer TW. Proof of the effect of testosterone on skeletal muscle. Journal of endocrinology: 2001; 170: 27-38.

3. Razul K.H, Aziz M.F. The effect of sustanon (testosterone derivate) taken by athletes on testis of rat. Jordan journal of biological sciences. 2012; 5: 113-19.

4. Karila T. Adverse effect of anabolic androgenic steroid on the cardiovascular, metabolic, and reproductive system of anabolic substance abusers. Academic dissertation: Institute of Biomedicine Pharmacology University of Helsinki, 2003. 
5. Epstein JI. the lower urinary tract and male genital system. Editor: Mitchel RN, Kumar V, Abbas AK, Fausto N, Aster JC. Pocket companion to Robbins and Cotran pathologic basis of disease. Edisi ke-8; Philadelphia: Saunders; 2012. h. 505-16.

6. Ascobat P. Androgen, Antiandrogen dan Anabolik steroid. Editor: Gunawan SG, Setiabudi R, Nafrialdi, Elysabeth. Farmakologi dan terapi. Edisi ke-5. Jakarta: Departemen Farmakologi dan Terapeutik Fakultas Kedokteran Universitas Indonesia; 2007. h. 468-80.

7. Sugeng SI, Tiono H, Anandaputri VN. Pengaruh pasta tomat (solanum lycopersicum) terhadap diameter tubulus seminiferus mencit (Mus musculus) galur $D D Y$ yang terpajan asap rokok berfilter. Jurnal Kedokteran Maranatha: 2010; 10: 47-54.

8. Anindita K, Sutyarso. Pengaruh pemberian vitamin $\mathrm{C}$ terhadap berat testis, jumlah sel leydig dan diameter tubulus seminiferus mencit (Mus musculus) jantan dewasa yang diinduksi monosodium glutamate. Skripsi. Lampung: Fakultas Kedokteran Universitas Lampung, 2008.

9. Hijazi MM, Azmi M.A, Hussein A, Naqvi SNH, Perveen R, Hijazi S. Androgenic anabolik steroidal-based effect on the morphology of testiscular structure of albino rats. Pakistan journal of zoology: 2012; 44: 1529-37. 